\title{
CAUSATION OF MONGOLISM
}

\author{
BY
}

\section{ENGLER}

\author{
(From St. Lawrence's Hospital, Caterham)
}

(ReCEIVED 9TH DeCEMBER, 1943)

EVER since Dr. Langdon Down in 1866 introduced the term " Mongolism," this group of aments has been the subject of numerous investigations. But so far the cause of Mongolism remains obscure and, in spite of a growing amount of literature, it is impossible to say whether there is a single cause for all cases of Mongolism or whether various etiological factors are to be held responsible.

Careful investigation of one-hundred and thirteen Mongols-seventy-five males and thirty-eight females-admitted to this Hospital during the last twenty years has enabled me to question the validity of the causes put forward by other observers and to form my own opinion as to the probable cause.

Very valuable contributions have dealt with the influence upon Mongolism of heredity-Brushfield, Fantham, Orel; of alcoholism and syphilis-Lind, Riddel, and Stewart; lack of vitamins and hormonesTredgold; fœtal hyperthyroidism-Clark; diminished potency of the secretion of the corpus luteumPenrose; and infusion of racial Mongolian blood into the family-Crookshank. Shortage of space compels me just to refer to these writers and their theories and ideas.

I shall now discuss exogenous factors having direct influence upon the pregnant uterus and would subdivide them into:-
A. Ill-health of the Mother.
B. The Theory of Exhaustion (Shuttleworth).
C. The Theory of Increased Amniotic Pressure.
D. The Theory of Nidation.

A. Ill-health of the Mother.-Tredgold reported that in a large proportion of his cases there was a history of ill-health, privation or anxiety of the mother during gestation. Brushfield goes so far as to say that among his one hundred and seventynine cases ill-health, privation or overwork of the mother was found in 34 per cent. of the cases. This is a very high figure indeed.

Among my own ninety-eight cases in seven or 6.8 per cent. there was considerable degree of illhealth, nervousness, worry or strain during gestation and I share the opinion of former writers that, though ill-health of the mother cannot be regarded as the sole causative agent, it certainly has some influence upon the development of the Mongol.
B. The Theory of Exhaustion.-Shuttleworth was the first to point out that the Mongol is the product of uterine exhaustion. He was able to show that the Mongol in the majority of cases is the last born of a large family, the mother's age being rather advanced at that time. Many other observers confirmed this view.

Among ninety-seven Mongols under my observation:-

3 were only children.

18 belonged to small families of only two children.

24 to families of three or four children.

16 to families of five or six children.

36 to families of seven or over seven children.

The position of the child among the other children was:-

7 were first born.

66 last born.

15 last but one.

8 were born in between the other children.

The ages of the mothers-seventy-nine were investigated-were:-

$\begin{array}{llllr}\text { below } 20 & \ldots & \ldots & \ldots & 1 \\ \text { between } 20 \text { and } 30 & \ldots & \ldots & \ldots & 14 \\ \text { between } 31 \text { and } 35 & \ldots & \ldots & \ldots & 9 \\ \text { between } 36 \text { and } 40 & \ldots & \ldots & \ldots & 32 \\ \text { between } 41 \text { and } 50 & \ldots & \ldots & \ldots & 21 \\ \text { between } 51 \text { and } 60 & \ldots & \ldots & \ldots & 2\end{array}$

The total over 35 being fifty-five, i.e. 70 per cent.

These data show that the majority of Mongols are the last born of rather large families, and that the age of the mother is rather advanced. I found the age thirty-eight remarkably often. On the other hand there are many young mothers among them. Some of the Mongols are first born and some belong to small families. Though the age of the mother and uterine exhaustion should not be neglected, they cannot be considered as the primary cause unless uterine exhaustion has a certain amount of influence upon the condition of the mucous membrane of the uterus with regard to the implantation of the impregnated ovum

C. The Theory of Increased Amniotic Pressure.Van der Scheer thought that as a consequence of certain abnormalities of the mucous membrane of the uterus the impregnated ovum is embedded under 
unhealthy conditions. This causes the formation of too narrow an amniotic sac and too high a pressure inside this sac so that even in the sixth or seventh week of embryonic life the development of the fotus is seriously impeded. He speaks of direct and indirect amniotic pressure and of poor blood supply to important parts of the fœtus. Van der Scheer's view is actually a basis for the next theory.

D. The Theory of Nidation.-Nidation is the implantation of the impregnated normal ovum into the mucous membrane of the uterus. It is well known that during the first few weeks after impregnation, the ovum does not get its nourishment through blood vessels, but is supplied solely by the surrounding tissues through osmotic pressure or osmotic activity.

In order to guarantee an adequate supply of nourishment and through it a normal development of the fotus, the mucous membrane at this early stage must be healthy. Any harm done to the mucous membrane shortly or relatively shortly before impregnation has taken place, be it by a toxin or by mechanical intervention, will cause an interruption of this normal vital supply to the ovum, and in certain cases may lead to a pathological development of the fotus, in some of them to Mongolism.

Professor E. Mayerhofer from the Königliche Universitäts klinik in Zagreb has published a very interesting article in the Annales Pediatrica 1939 about the causation of Mongolism. He observed among his young and well-to-do married patients that the number of first born Mongoloid children is on the increase. According to his views, these young people have no desire to have children. They, therefore, use abortifacients or the curette. When pregnancy occurs later, the first child often is a Mongol. As far as I am aware, he is the first to introduce a new term in the history of Mongolism, that of the so-called "Curettage Mongol.",

Among ninety-eight Mongols I found twelve definite cases where miscarriage in the mother due to the use of abortifacients, or curettage, or miscarriage of unknown origin immediately preceded the birth of the Mongol. It should be remembered that I was dealing with people who, to some extent, are not interested in their children and were very reluctant to give any kind of information. In some cases I had the definite feeling that the mothers gave me deliberately false information. I am sure I am not wrong in assuming that the number 12 or $12 \cdot 7$ per cent. is a too low one and that it would have been far higher if my informants had been unbiassed. Also it should be realized that my informants belong to a class of people on whom curettage is not often performed, for they generally use abortifacients. Investigations among well to do people would probably lead to far higher figures than those mentioned in this paper. Here are some short references of my cases:-

Case 1.-A. T. W., male, aged twenty-nine. His father and mother are alive and healthy. The age of the mother at the birth of the defective was thirty-eight years.
Brothers and sisters:

1. and 2. Twins, both male, normal, now 39.

3. and 4. Twins, male and female, normal, 37.

5. Male, normal, now 36.

6. Male, normal, now 34.

7. MisCARRIAGE, through curettage.

8. The defective.

9. and 10. Twins, male normal, now 25.

Case 2.-A. D. M., male, aged twenty-three. The mother was forty-one at the defective's birth. A first cousin on the father's side has a boy of five who is a Mongol.

Brothers and sisters:

1. Male, now 35, normal.

2. Female, now 33, normal

3. Female, now 26, normal.

4. MisCARRIAGE, through curettage.

5. The defective.

Case 3.-S. G. St., male, aged twenty-four. The father and mother are both alive and healthy. An aunt of the patient is a defective. The mother was thirtyeight years old at the defective's birth.

Brothers and sisters:

1. Female, died at the age of $\mathbf{3}$ days of Peritonitis.

2. Male, now 32, normal.

3. Miscarriage, caused by shock during last war.

4. The defective.

Case 4.-M. K., male, aged twenty. The father was thirty-nine, the mother forty-one at his birth.

Brothers and sisters:

1. Female, now 43, normal.

2. Female, now 41, normal.

3. Female, now 39, normal.

4. Female, now 37, normal.

5. Female, now 35, normal.

6. Male, now 33, normal.

7. Miscarriage.

8. Female, now 31 , normal.

9. Male, now 29, normal.

10. Male, died at 13 years with rheumatic fever.

11. Male, now 24, normal.

12. Male, now 21, normal.

13. MiscARriage, caused by abortifacient.

14. The defective.

Case 5.-B. M. H., female, aged thirty-two. The mother was thirty-eight years old at her birth.

Brothers and sisters:

1. Female, now 45 , normal.

2. Female, now 42, normal.

3. Male, now 39, normal.

4. Male, now 37, normal.

5. Male, now 35, normal.

6 . Male, now 33, normal.

7. MisCARRIAGE.

8. MISCARRIAGE, both caused by abortifacients.

9. The defective.

Case 6.-G. W. B., male, aged seventeen. The mother was forty-seven at the defective's birth.

Brothers and sisters:

1. Male, now 42 , normal.

2. Female, now 41, normal.

3. Male, now 35, normal.

4. Male, now 30, normal.

5. Male, died at the age of five months.

6. Miscarriage, due to shock.

7. The defective.

Case 7.-S. N., female, aged eighteen. The father was thirty-five, the mother thirty-four at her birth.

Brothers and sisters:

1. Female, now 28 , normal.

2. Female, now 25, normal.

3. Miscarriage, after five months, due to shock.

4. The defective. 
Case 8.-C. S. G., female, aged twenty-seven. The mother was forty-eight years old at her birth.

Brothers and sisters:

1. Male, normal.

2. Female, died of Tuberculosis after whooping cough.

3. Male, normal.

4. Male, normal.

5. Male, normal.

6. Male, normal

7. Male, died of Meningitis after whooping cough.

8. Male, normal.

9. MiscarRiage, reason unknown.

10. The defective.

Case 9.-R. J. B., male, aged twenty-three. The father was thirty-six, the mother thirty-nine at his birth. Brothers and sisters:

1. Male, normal.

2. Female, normal.

3. Male, normal.

4. Female, normal.

5. Female, normal.

6. MisCARRIAGE, caused by curettage.

7. The defective.

Case 10.-A. J. B., male, aged thirty. The father was forty two, the mother forty at the defective's birth.

1. MiscarRiage.

2. Stillbirth.

3. Died at two weeks of " uræmic convulsions."

4. The defective.

I presume though I could not prove it that parental syphilis was in this last instance the cause of the miscarriage and the stillbirth.

Besides the twelve cases where miscarriage immediately preceded the birth of the defective which could be established beyond doubt, I would like to cite another case.

Case 11.-W. B. Th., male, aged sixteen.

Brothers and sisters:

1. Female, now 29, normal.

2. Male, now 28 , normal.

3. The defective.

The mother who was thirty-six at the defective's birth, had a prolapse of the uterus previous to the birth of the defective.

In all these cases we see normal births and normal children until a miscarriage has taken place, and the birth of a Mongol after a miscarriage. It is irrelevant whether the miscarriage was caused by mechanical intervention-curettage, by intake of irritants - abortifacients, or was caused by shock or by syphilis. In all these cases I could ascertain that the birth of the Mongol following such a miscarriage took place approximately one year later which would mean that the implantation of the new ovum took place only a few months after the miscarriage.

As has already been pointed out, miscarriage causes a serious alteration of the mucous membrane of the uterus, especially in persons with a morbid heredity. Here the implanted ovum will find pathological conditions, its nourishment will be seriously hampered, and within the first few weeks of fotal life the foundation for a Mongolian child will be laid. Apart from morbid heredity, illhealth of the mother, strain, overwork or any other cause which would interfere with the health and thus lower the normal resistance of the tissues, will contribute towards this condition.

It is, of course, difficult to assess what time is needed to restore normal conditions in a tissue which has suffered through toxins or mechanical intervention. In some persons, especially in healthy and fairly young ones, healing may be rapid and the implantation of the new ovum will take place under conditions favourable to its nutrition. If, on the other hand, many births have preceded the miscarriage, or the healing tendency of the tissues is slowed down by toxins, syphilis or anything else, a long time may elapse before normal conditions are restored.

How far, and whether at all, the prolapse in my last case influenced the birth of the Mongolian child, I am unable to say. I mentioned this case in connection with my other cases as a matter of interest.

\section{Summary}

In a review of over one hundred cases of Mongolism I have tried to form an opinion as to the cause of this amentia. Based on morbid heredity, the unhealthy condition of the mucous membrane of the uterus at the time of the implantation of the impregnated ovum seems to me to be the chief cause of Mongolism. One of the main factors contributing to this unhealthy condition is miscarriage, irrelevant whether brought about by curettage or by the use of abortifacients.

I wish to thank Dr. Edmund Nobel who has inspired me to investigate Mongolism and has given me valuable advice. I am also indebted to the Med. Superintendent Dr. T. Lindsay, the Deputy Med. Superintendent Dr. D. P. Firmin, and to Dr. D. Bryan of the above Hospital for giving me their help and advice.

\section{REFERENCES}

Brushfield, Thomas (1924). Brit. J. Child., 21, 241-58. Crookshank, F. G. (1931). The Mongol In Our Midst, 3rd edit, Kegan Paul, London.

Fantham, H. B. (1925). S. Afr. J. Sci., 22.

Down, J. Langdon (1866). London Hosp. Rep., 111, p. 259.

Lind, W. A. T. (1923). Med. J. Austr., 11, 272.

Orel in Nobel, E. (1939). Innere Secretion und Konstitution im Kindesalter, Wien.

Penrose, L. S. (1932). J. Genet., 25, 407-22.

Riddel, D. O., and Stewart, R. M. (1923). J. Neurol. Psychopath, 55, 221.

Van der Scheer, W. M. (1927). Abh. Neurol., Psychiat., Psychol. Grenzgebieten, Heft. 41, Berlin.

Tredgold, A. F. (1929). Mental Deficiency, 5th ed., pp. 213-25. 